\title{
An Inquiry into Adolescents' Experiences with Cognitively Demanding Writing: Time Investment and the Importance of Authenticity
}

\author{
JENNIFER MITTON-KÜKNER \\ St. Francis Xavier University \\ HEATHER MICHAEL \\ Columbia University
}

\begin{abstract}
In this paper, we describe our 12-month inquiry into understanding adolescents' experiences, as they engaged in writing that challenged them to construct knowledge by making claims grounded in evidence and reasoning. As they engaged in the task of writing a research paper, participants' perceptions of time were two-fold in that they consistently identified a lack of time and a lack of understanding about the time the research paper demanded. We argue enabling students to have more temporal control over their writing is related to fostering increased metacognition about writing as a process.
\end{abstract}

\section{Introduction}

I kind of use the analogy of a train...

So, a train takes a really long time to get going, and it's the same thing with the extended essay, it took a really long time to get going.

But once I got into it,

I just zoomed.

It's the same thing with a train ride;

it takes a really long time to get going, but once it does, it just zooms.

It's the same thing with my extended essay;

a typical day, at first, was monotonous.

Trying to gather data for my analysis,

but once I got all that data,

and I figured out...my arguments,

it just flew.

(Paul ${ }^{1}$, found poem excerpt, based upon interview November 13, 2015)

There is an abundance of literature demonstrating the considerable interest researchers have in understanding more about adolescents' literacy practices in and outside of school (Collie et al., 2016; Moje et al., 2008; Scott Curwood, Magnifico, \& Lammers, 2013; Troia, Shankland, \& Wolbers, 2012; Villalon et al., 2015) and identifying ways to engage and support secondary youth in meaningful writing practices (Benko, 2012; Bonsur Kurki, 2015; VanDerHeide \& Juzwik, 2018). Our aim in this paper is to contribute to these

${ }^{1}$ All names, people and places, are pseudonyms. 
areas; to do so we maintain a focus on 10 secondary adolescents' perspectives on, and use, of time, as they engaged in the development of a demanding writing task over 12 months. The results of this study not only complement what is known about the teaching of writing and secondary youth, but, also, provide insights into what is unknown; specifically, how youth perceive and use time for the purposes of writing. Using a thematic, narrative, artsinformed approach (Butler-Kisber, 2010), this paper qualitatively explores experiences of high school students involved in the International Baccalaureate Diploma Programme (IBDP), as they developed a research paper. The 4000-word research paper, known as the Extended Essay (EE), offers students to engage in independent research on an area of interest within a chosen subject or combination of subjects in the IBDP (Wray, 2013). Attending to participants' understanding of time, as it was perceived and invested, provided insights into their thinking regarding this demanding writing task.

In the opening poem, a grade 12 student, Paul reflects upon the experience of developing a first-time research paper as part of his studies in the IBDP. As a high school student involved in a rigorous academic program, Paul was expected to engage in the writing of advanced disciplinary writing tasks and had ongoing opportunities to write in different genres and for different purposes (Jeffery \& Wilcox, 2014). What was different about this writing task, however, was that Paul was expected to create and sustain an original argument using published literature to inform his claims. Paul described the thinking and writing needed for the EE as slow to mature; it took time to conceptualize his argument although, he noted, once this had happened, its development occurred at a steady pace. Paul's insights about his own writing process highlighted temporal elements, as he described the thinking momentum that was required for the EE's progression. Scholars of the IBDP have found that while students perceive the EE as challenging with respect to a range of factors (learning strategies, classroom context, teacher knowledge, scheduling) impacting students' potential success (Hamer, 2010), research also demonstrates the positive, long-term effects of the EE (Aulls \& Lemay, 2013; Aulls \& Pelaez, 2013). Scholars have found that graduates of the IBDP credit the EE with preparing them for university level writing; they were more familiar with the steps of an extensive paper, better able to gather and assess references, and knowledgeable of academic style appropriate for field of study (Aulls \& Lemay, 2013; Aulls \& Pelaez, 2013; Inkelas, Swan, Pretlow, \& Jones, 2012; Wray, 2013;).

Echoing the scholarship about the benefits of the EE, much has been written about the multiple advantages that regular opportunities to write in school afford for secondary youth. Some examples attribute regular writing to: the development of advanced writing abilities (Jeffery \& Wilcox, 2014), increased understanding of content (Graham \& Herbert, 2010), overall quality of student work (American Institutes for Research, 2005, 2007), and achievement on writing (Graham, Harris, \& Hebert, 2011) and standardized assessments (Matsumura, Slater, Garnier, \& Boston, 2008; Newmann, Bryk, \& Nagaoka, 2001). While there is strong evidence of the benefits regular writing can foster, the kinds of writing in which youth engage and produce are also important (Villalon, Mateos, \& Cuevas, 2015). Tasks that challenge students to move beyond summarizing single sources to consult two or more references, with the aim of synthesizing such information to inform an argument, are critical to learning. Engaging in such kinds of writing tasks, researchers have argued, can lead to positive learning outcomes (Aulls \& Shore, 2008; Thomson \& Gunter, 2006; Fielding \& Bragg, 2003), the development of inquiry-based literacy skills (Shore et al., 
2009), and strong student engagement (Collie, Martin, Scott Curwood, 2016; Jeffery \& Wilcox, 2014). Although scholars agree that writing, and the instruction of writing, should be educational priorities, as writing engagement contributes to development of thinking, learning, and communicating (Graham \& Perin, 2007; Graham, Harris, \& Hebert, 2011; National Commission on Writing for America's Families, Schools, and Colleges, 2003), the teaching of challenging, extended writing tasks, is the exception in schools (Applebee \& Langer, 2009; 2011; Benko, 2016; Bryk, Nagaoka, and Newmann, 2000; Fisher, 2009; Matsumura et al., 2008). Little is known about secondary youths' experiences in and perceptions of engaging in such kinds of writing.

Of particular interest to our focus was adolescents' perspectives on, and use of, time in writing extended arguments. A review of the literature revealed only a handful of studies that focused directly on time-related elements associated with the development of extended writing, with the bulk of these studies focused on the time allocation of teachers regarding their instructional practices in literacy and language arts classrooms (Fisher, 2009; Swerling \& Zibulsky, 2014; Zenkov \& Harmon, 2009). The remainder indirectly referenced aspects of time; for example, in how to support secondary youth at different stages of the writing process (Benko, 2012; VanDerHeide \& Juzwik, 2018) and in how to engage them in writing through alternative approaches (Bonsur Kurki, 2015; Calderón López \& Thériault, 2017; Price \& Harkins, 2011). A rare find in our review was the work of Roca de Larios, Manchón, Murphy, and Marín (2008), in which they found argument formulation took up the greatest amount of time for adolescent and young adult learners of English. Overall, there is limited research on how secondary adolescents perceive writing (Juzwik et al., 2006), on how they sustain their efforts during the development of a cognitively demanding writing task (Benko, 2016), and, little to no research, on how they perceive and allocate time in writing extended arguments. Of importance to this study was understanding youths' perspectives and experiences, as they engaged in the writing of a task that challenged them to construct knowledge and expand on their thinking by making claims that were grounded in evidence and reasoning.

In our 12-month study, we attended to the experiences of 55 IBDP students as they worked on the development of the EE. Our focus in this paper is on 10 of these participants through the following four-fold purpose: (1) to burrow into the experiences youth reported as they developed this research paper; (2) to consider how perceptions of cognitively demanding tasks shaped participants' willingness, if any, to persist with the development of this research paper; (3) to understand how perceptions of time informed the development of the EE; and (4) to identify the presence of time pressure, if any, in response to busy schedules, and the ways this may have shaped their writing engagement. In what follows, we explore the experiences of 10 adolescents developing and writing a research paper.

\section{Theoretical Framework}

Due to the nature of the Extended Essay (EE), a paper that requires students of the IBDP to independently identify a research worthy topic and sustain an original argument, it was imperative to the design of the study to inquire (Butler-Kisber, 2010) into the stories adolescents told over time of their writing experiences. Informing our thinking in this study was an understanding of twenty-first century literacy and its multi-faceted emphasis on learning and literacy practices in technologically advanced societies. Identifying literacy in this way embraces not only reading and writing, but also methods and ways of thinking 
used for a variety of purposes such as comprehension, communication, critical thought, and construction of knowledge (Gee, 2001, 2007; Kalantzis \& Cope, 2011; Kane, 2011; Lind, 2008; Pahl \& Rowsell, 2012; UNESCO, 2008). The complexity of the social world is at the center of such thinking about literacy and acknowledges the multiple responses and behaviors that occur as individuals interact with others in particular places, shaped by contextual parameters and social requirements (Beach, Appleman, Fecho, \& Simon, 2016; Downer, Sabol, \& Hamre, 2010 ). To further sharpen our gaze on secondary adolescents' perspectives of engaging in a task that challenged their thinking and writing, we drew upon two central concepts in our framework: First, the EE as a cognitively demanding writing task (Benko, 2012, 2016) and second, the presence of time (Duncheon \& Tierney, 2013) informing participants' understanding of the kinds of thinking and writing that the EE demanded.

Over the course of the study, participants regularly referred to the EE as intellectually and temporally demanding, with perceptions seemingly shaped by not only its research orientation but, also because it was largely self-directed and externally moderated. Benko $(2012,2016)$ categorized cognitively demanding writing tasks (CDLTs) as undertakings that ask, "students to (1) construct knowledge rather than restate or summarize and (2) elaborate on their thinking by making claims and using evidence or reasoning" (p. 202). As participants engaged in the development of the EE, it became apparent to them that the thinking, writing, and expectations associated with this task were far more complex than what they had previously encountered in prior schooling experiences. As we collected data and, later, in our analysis of participants' accounts, we were drawn to moments in which they made this struggle visible through their growing awareness of the task's temporal implications, particularly the time they had to invest into thinking and writing and that it was not a paper that one could competently complete quickly. Indicators of participants' thinking regarding the development of the $\mathrm{EE}$ were most intricately connected with concepts of time. To describe progress, if any, that was being made regarding the EE's development, required participants to articulate the decisions they made at different stages of its conceptualization. These decisions were temporally bounded in nature and tied to different stages of the research-writing process, particularly as their thinking deepened in response to the interrelated phase of reviewing research related to their topic and composing an argument that reflected the published literature as they also attempted to propose new understanding.

Lastly, further heightening our awareness of participants' time-related references as part of their writing engagement is Duncheon and Tierney's (2013) conceptualization of $21^{\text {st }}$ century time constructs in which they identified three temporal paradigms important to the teaching and learning process, specifically clock time, socially constructed time, and virtual time. Of the three constructs discussed, Duncheon and Tierney described socially constructed and virtual time as subjective paradigms in which socially constructed time accounted for perceptions of "diversity, quality, and meaning" (p. 249) and virtual time lived in relationship to information and communication technologies (ICTs). Individuals' experiences using ICTs, the authors explained, are "more varied, complex and fast paced...directly contradict[ing] assumptions inherent in clock time" (p. 253). Unlike socially constructed and virtual time, clock time, is "measurable" and used to identify behaviors and perceptions associated with "quantifiable time allocations" (Duncheon and Tierney, p. 243). Duncheon and Tierney's three temporal paradigms enabled us to reflect 
upon the frequency and nature of adolescents' time related references related to the planning, development, and writing of the EE. In the design of the study, we were mindful of the importance of time to participants' understanding of the EE, having encountered former students' insights and experiences with the EE in the two years (2012-2014) leading up to year of the study (2014-2015). Of particular interest were moments leading up to the completion of the EE in which participants articulated their growing understanding of their research topic in relation to the developing sophistication of their argument; in such moments, they reportedly experience a loss of time, immersed as they were in the writing. Conversely, at the outset of this process, participants also described moments where they felt a sense of stalled time, particularly when their understanding of their research topics was still developing.

Considering the interplay of CDLTs with attention to time constructs not only allowed us to further burrow into participants' thinking as it was temporally distributed (Roca de Larios et al., 2008) over the course of this challenging writing assignment, but, also enabled us to pinpoint their understanding of the time investment it demanded.

\section{Methodology and Methods}

Conducted in the academic year of 2014-2015, the study was situated in an urban high school where the Authors ran a curriculum project focused exclusively on supporting IBDP students' understanding of the EE. In brief, the IBDP is a two-year academically demanding programme for grade 11 and 12 students, ages 16-19. Established in 1968, as a non-profit educational foundation ("History of the International Baccalaureate", n.d.), the IBDP is offered throughout the world and Canadian schools have experienced rapid increases over the past five years in their offerings of IBDP programmes. There are approximately 141 IBDPs and 20,000 students in Canada ("Today in Canada", n.d.); presently in Nova Scotia, the IBDP is offered in 13 public high schools ("International Baccalaureate in Nova Scotia", n.d.) and two private schools. In the IBDP, students are expected to study courses from six different subject groups; additionally, students are also expected to engage with three core elements: the extended essay (EE), theory of knowledge (ToK), and creativity, action, service (CAS). At the time of the study, there were 55 Year 1 students and 64 Year 2 students involved in the IBDP in this school. The IBDP students were part of a student body of 1350 students.

The curriculum project, entitled Project Worldview (PW), first began in the fall of 2012 and was developed in response to Heather Michael's observations that students often struggled with initial steps of the EE, particularly the importance of identifying a research worthy topic. In total, PW happened over three academic years (Year 1: 2012-2013; Year 2: 2013-2014; Year 3: 2014-2015) and each year was comprised of approximately 11 sessions in which grade 11 students explored theories of knowledge, research paradigms, personal research interests, and peer-reviewed literature related to their identified topics. At the end of the school year, PW concluded with a research showcase where students shared their research topics, proposed plans for the EE, and any initial drafts they may have 
developed $^{2}$. The classes scheduled for PW were not a part of any other class/subject and students did not receive grades for attending these sessions. Observing students' responses to PW, particularly its impact upon developing their understanding of the EE and the research process, encouraged us to conduct this study in 2014-2015 into students' experiences with the overall development of the EE.

\section{Data Collection Methods}

As part of the larger study involving 55 IBDP students in grade 11, the data collection methods included: two questionnaires comprised of open-ended questions (administered in December 2014 and May 2015), 11 observations (22 sets of field notes) on PW sessions (December 2014-June 2015), student samples of work, and 30 audiorecorded semi-structured interviews conducted by Author A (Interview One: December 2014; Interview Two: May 2015; Interview Three: November-December 2015). Important to note is that two of these interviews occurred during PW and the final interview happened in the fall of participants' grade 12 year. The interviews, running approximately 20-40 minutes, included questions about their research and writing experiences in school as well as about the development of the EE. The 10 students who were interviewed about their experiences are the focus of this paper. The following chart depicts information participants shared about themselves. In general, the 10 adolescents could be described as academically successful, active in extra-curricular activities, in and outside of school, engaged in a wide range of interests, from middle-income families, and of European origin. Of the topics chosen for their EE, nine of 10 participants made explicit connections between their EE topic $^{3}$ and their personal interests and extra-curricular activities.

Table 1

\section{Participants}

\begin{tabular}{|l|l|l|l|l|}
\hline $\begin{array}{l}\text { Names of } \\
\text { participants }\end{array}$ & Gender/Age & $\begin{array}{l}\text { Identified } \\
\text { interests }\end{array}$ & $\begin{array}{l}\text { Extra- } \\
\text { curricular } \\
\text { (school or } \\
\text { community } \\
\text { based) }\end{array}$ & $\begin{array}{l}\text { Preferred school } \\
\text { subjects (if identified) }\end{array}$ \\
\hline Bryce & Male/16 & $\begin{array}{l}\text { Music } \\
\text { (oboe, } \\
\text { piano) }\end{array}$ & Band & Social studies/math \\
\hline Grace & Female/16 & Sports & Basketball & Unidentified \\
\hline Joseph & Male $/ 16$ & $\begin{array}{l}\text { Sports, } \\
\text { debating, }\end{array}$ & $\begin{array}{l}\text { Debate } \\
\text { team, }\end{array}$ & Sciences \\
\hline
\end{tabular}

\footnotetext{
2 The overall purpose of PW was to help grade 11 students identify a research topic for the EE. The research showcase in June celebrated their efforts and required students to create an academic research poster to summarize their topic and plans for developing the paper. Students, parents, and teachers attended this event. Some students also developed drafts of their EE for this event; however, the majority wrote their EE over the summer into and fall of grade 12 and completed the EE in December.

${ }^{3}$ Participants' extended essay topics are not divulged to enhance anonymity.
} 


\begin{tabular}{|c|c|c|c|c|}
\hline & & $\begin{array}{l}\text { volunteer } \\
\text { work }\end{array}$ & $\begin{array}{l}\text { hockey, } \\
\text { tutoring }\end{array}$ & \\
\hline Julia & Female/16 & Swimming & $\begin{array}{l}\text { Swim team, } \\
\text { works part- } \\
\text { time }\end{array}$ & Theory of knowledge \\
\hline Lori & Female/16 & $\begin{array}{l}\text { Music, } \\
\text { theatre, } \\
\text { horseback } \\
\text { riding, } \\
\text { Volunteer } \\
\text { work }\end{array}$ & $\begin{array}{l}\text { Student } \\
\text { council, } \\
\text { coaching, } \\
\text { fund raising } \\
\text { for local } \\
\text { camp }\end{array}$ & Unidentified \\
\hline Nicholas & Male/16 & $\begin{array}{l}\text { Music } \\
\text { (piano), } \\
\text { creative } \\
\text { writing } \\
\text { (sci-fi) }\end{array}$ & $\begin{array}{l}\text { Band, Model } \\
\text { United } \\
\text { Nations, } \\
\text { works part- } \\
\text { time }\end{array}$ & Unidentified \\
\hline Paul & Male/16 & $\begin{array}{l}\text { Sports, } \\
\text { movies, } \\
\text { economics }\end{array}$ & Football & Unidentified \\
\hline Reese & Male/16 & $\begin{array}{l}\text { Sports, } \\
\text { chess, } \\
\text { space }\end{array}$ & $\begin{array}{l}\text { Soccer, } \\
\text { cross- } \\
\text { country, } \\
\text { hockey, } \\
\text { chess, } \\
\text { student } \\
\text { council, } \\
\text { drama, } \\
\text { piano } \\
\text { lessons }\end{array}$ & Math/science \\
\hline Talia & Female/16 & Sports & $\begin{array}{l}\text { Hockey, } \\
\text { sailing }\end{array}$ & Math/science \\
\hline Yolanda & Female/16 & $\begin{array}{l}\text { Music } \\
\text { (guitar), } \\
\text { movie } \\
\text { making, } \\
\text { traveling, } \\
\text { volunteer } \\
\text { work }\end{array}$ & $\begin{array}{l}\text { Community } \\
\text { involvement } \\
\text { (youth } \\
\text { social } \\
\text { justice), } \\
\text { volunteer } \\
\text { work }\end{array}$ & English/history/sciences \\
\hline
\end{tabular}

\section{Analysis and Representation of Data as Found Poems}

Data was inductively analyzed throughout the inquiry to better understand participants' experiences over the course of developing the EE. Inductive analysis increased our awareness of recurring patterns across participants' narrative accounts and heightened the attention we paid to participants' perceptions of time, particularly a lack of time and the amount of time the EE demanded. The presence of this two-fold tension 
seemed to influence participants' understanding of the EE, particularly the amount of time they thought they were able to invest in related thinking and writing activities. Our decision to represent the data as found poems (Butler-Kisber 2002, 2010) clustered around variations of the phenomenon (Butler-Kisber \& Stewart, 2009), was based upon our aspirations to vividly display participants' thinking about the EE through perceptions of time and accounts of time use and to show pockets of learning in response to struggles (Mitton-Kükner, 2013, Mitton-Kükner, 2015; Michael \& Mitton-Kükner, 2016). Creating found poetry is a creative process and entails what Butler-Kisber (2010) described as "the rearrangement of words, phrases...taken from other sources and reframed as poetry by changes in spacing and/or lines or by altering the text by additions and/or deletions" ( $p$. 84). Developing the poems required numerous readings of transcripts to first establish common patterns, followed by identifying words and phrases (Butler-Kisber, 2010) depicting participants' descriptions of their thinking and writing engagement. Early impressions of the ideas found in the poems were shared with participants in the final interview to create an opportunity for their feedback. Only minor changes to grammar and arrangement of participants' words occurred during the creation of these poems and may be viewed as "untreated" (Butler-Kisber, 2010).

\section{Findings}

Adolescent Temporal Perspectives on Cognitively Demanding Writing: Experiences of Time Pressure and Willingness to Invest Time

The following found poems ${ }^{4}$ demonstrate what each of the 10 participants reportedly experienced as they worked towards the completion of the extended essay amongst competing academic demands. The selections, each about a different participant, were chosen to epitomize recurring experiences shared by all 10 participants over the course year in which data was collected and, again, in the final interview as participants looked back upon the experience. Participants' perceptions of time were two-fold in that they consistently attributed specific commitments as responsible for their lack of time, working in combination with a lack of understanding about the time the extended essay demanded. The presentation of the four themes are organized to demonstrate participants' busyness in and out of school, their initial lack of understanding about the time the EE demanded, their gradual comprehension of the time they needed to dedicate to the EE, and their perceptions of the EE's authenticity with their willingness to invest time.

\section{Mutual Experience ${ }^{5}$ 1: Juggling Competing Demands: Grace}

Well, it's for sure busy, that's for sure!

Time!! I don't have any of it, I love working on it [extended essay], it's interesting and I want to sit down and do it, but I have a million other things going on.

\footnotetext{
${ }^{4}$ The larger data set associated with this study includes 30 poems related to 30 interviews conducted over the 2014-2015 academic year.

5 The phrase "Mutual Experience" is used to describe encounters reported by all 10 participants.
}

Language and Literacy $\quad$ Volume 21, Issue 1, $2019 \quad$ Page 82


I usually wake up around 7:50,

get up,

go to school,

do school all day...

really my only break is lunch where I eat,

sometimes I can barely eat!

Then usually I'll go home, eat, then go to practice...

I play basketball! It's super busy!

It's really hectic, we have really late practices.

We usually have 8-10 practices [a week] which are mostly two hours...

My mom lives [close to school],

but my dad lives in [the city], and

last week we had conditioning from 5-6,

and then practice from $8-10$,

and I didn't get home until like 10:30...

By the time I showered...it was 11,

So, I couldn't do anything.

I had a huge bio test the next day too!

It's a little stressful right now...

November, they [teachers] said, it's going to be the hardest month

because they're just piling everything on,

and everything's getting due,

and they're introducing new things.

Chem IA [Internal assessment], the Bio IA...

the extended essay due...a TOK essay...

there's just so much stuff that's due!

It's just very hectic right now...

(Grace, found poem based upon Interview 3, November 13, 2015)

Unpacking Grace's experiences. For Grace, like all of the participants, finding time for the extended essay seemed to compete with other school related commitments, academic as well as extra-curricular. While Grace described a desire to work on her extended essay, particularly as Grace had personal interest in the topic, overwhelmingly a lack of time was attributed to the intensity of school life. Grace was aware of this tension and acknowledged that her schedule sometimes meant she was ill-prepared for particular assessment tasks. Viewing Grace's reported efforts to engage with her extended essay in terms of time allocation (Hillbrecht, Zuzanek, \& Mannell, 2008) suggests that Grace, and the other participants, felt pressed for time throughout this process. Regular engagement in activities like part-time work, school athletic teams, the school band, volunteer work, and school assignments were reported by all participants as placing demands upon their time. Grace, and others, described this hectic pace as a regular experience in the IBDP and indicated the choices they had to make in terms of trade-offs (Hillbrecht et al., 2008) of where they felt they could allocate time in response to the structural and academic expectations of school life. In many ways, engaging in the development of the extended essay long before it was actually due meant, for Grace and her peers, sacrificing their 
attention from something else. Yet, despite the intensity of their schedules, participants largely reported that their experiences taught them how to manage time and prioritize commitments.

\section{Mutual Experience 2: (Mis)perceptions of Time Investment and the EE: Bryce}

It took me a while to stumble onto a topic

that was really solid.

I had an immense amount of knowledge,

about a broad topic,

which didn't necessarily apply to what I wanted to do...

It slowly evolved.

It took a really, really long time,

sifting through information,

to try and figure something that really applied...

That idea of refining your information or

knowing where to look to find information,

that was really a big process for me.

I've kind of gone away from...getting mega overwhelmed,

because there is so much information,

to finally getting to where I want.

But it's knowing where to look, and

then knowing where to get information,

and then what to do with it afterwards.

I was just like [initially],

I don't know what to do with myself...

Eventually looking through [the sources], and

using the good old CTRL + F [function],

I eventually found what I wanted.

Refining that information from the broad topic

to the topic ${ }^{6}$ that I have right now,

that process I could have done from the beginning.

If I [had] had a solid question right off the start,

I would have probably analysed my data a little differently...

MAYBE...

(Bryce, found poem based upon Interview 3, November 13, 2015)

Unpacking Bryce's experiences. Bryce was forthcoming as he described the cognitive challenge of navigating large amounts of research literature while attempting to identify an angle that would enable him to make his claim. Making time for the EE was

${ }^{6}$ All of the participants used the word, "topic", to represent their argument in the EE. 
described by Bryce, and the other participants, as multi-faceted in that there was the time needed to identify, and understand, suitable references followed by the more substantial undertaking of creating a plausible argument. In this instance, Bryce's words bring to light what all of the participants identified about the EE, in that, not only was it a time-intensive process; but, it was the kind of writing they had limited experience doing. This writing task demanded they develop a research worthy topic with the aim of constructing knowledge using evidence (Benko, 2016) from information-dense texts. Bryce explained that once he became more familiar with the field, as well as the argument he wanted to sustain, he was better able to navigate such texts, for example, in the use of keyboard shortcuts to identify key words. In looking back on the process, Bryce suggested he might have been able to go about the development of EE differently had he spent more time creating a research question on which to focus his efforts. Bryce's insight, in the moment, was tentative, as he followed the comment up with much laughter and emphasized the word, "maybe", to show his uncertainty.

\section{Mutual Experience 3: Closer to the End: Waking Up to the Time Needed for the Task: Lori}

You need to structure your time effectively, everyone will tell you to do work during the summer, I didn't do enough work during the summer.

You have this big project, and you have a lot of time, but when you throw in all the other things, things get missed.

Some challenges are time management.

In the IB program a lot goes on...

Learning how to plan and prepare is a challenging thing to do.

The evenings and weekends are definitely busy;

I try to do more of the writing in the morning.

However, weekends are an excellent time if

I can just chunk of a couple of hours.

That's certainly been helpful.

I just block off time for writing

as one due date gets closer that becomes the priority.

Picking an extended essay topic is not super easy.

I'm still happy with my topic; but,

I did have to change what I wanted to do.

That was hard for me;

I really liked the idea of what I had.

But it's important to recognize what you can and can't do.

I was a little bit ambitious.

So that was challenging!

My advice would be, if you are interested in collecting your own data, 
you have to be really on top of the research and the timeline.

The extended essay could be a wonderful process, but

you absolutely need to pick a topic you're passionate about.

It's an interesting way to learn about yourself,

your study habits,

your time management,

your interests, and

also, how you work as a writer, or

how you work as a researcher.

It's good in the sense of preparing you for University!

[But] there will be some things,

I will be wishing I'd done more earlier.

(Lori, found poem based upon Interview 3, November 13, 2015)

Unpacking Lori's experiences. All of the participants suggested that if they were to advise someone who was about to begin their EE, they would emphasize beginning early. Lori acknowledged the importance of finding time for the EE over the spring and summer of grade 11 rather than leaving this task to be completed in the fall of grade 12. Yet, Lori and the other participants conceded beginning early was challenging to do, because of the ongoing workload in the IBDP and the amount of time and energy this kind of writing entailed. Lori's described her process of writing, as learning how to block off time for the task. During the interview, Lori was quick to emphasize that identifying one's argument in the EE was challenging to do and was not something that happened quickly. Lori, unlike the majority of participants ${ }^{7}$, at the beginning of the EE was quite intent on gathering original data through the use of a survey. However, she soon learned this would add time to the task (time she did not have) and because of this, had to revise her original aim to focus her argument more upon a meta-analysis of other research. Lori noted that passion for one's topic was critical to the development of the EE and judged the task as highly authentic in terms of her post-secondary and professional goals (Behizadeh, 2014), a point echoed by all of the participants throughout the study's duration.

\section{Mutual Experience 4: Perceptions of Authenticity Intersecting with Willingness to Invest Time: Yolanda}

Practicing your time management skills.

The time [needed] that's an advantage and disadvantage.

So, that's definitely a challenge, for all of us.

because everything else due in all of your other classes.

The extended essay is interesting it's bigger than most of the standard essays we write in high school, it just kind of brings a few disciplines together, [and] it's great preparation for University.

\footnotetext{
${ }^{7}$ Participants in the study relied on peer reviewed references to develop their EEs and did not collect original data or conduct experiments.
} 
I love my topic,

it's something I'm really passionate;

The goal...has always been to prove that youth have the ability

to do all these great things.

All of them have leadership.

My topic came because in Grade 11

I was heavily involved in a lot of service learning projects,

and a lot of school clubs so,

it just kind of seemed natural to me

do something I'm interested in.

Yet, I still have to force myself to sit down and write.

I also love writing so it's really weird.

At one point I was thinking,

do I keep writing about this topic that I am passionate about?

That requires more work?

Or do I change my topic to something that I've already done research on?

It'll be a lot easier, faster to write, and I could get a decent mark out of it...

I like how working with the different disciplines

gives you different perspectives on things,

to not be narrow-minded; but,

to realize where you are,

where you stand,

and then

after you realize your views,

you can learn from others and how they perceive things.

With the extended essay,

it gives you the ability to research a specific topic,

but look at it from different perspectives.

(Yolanda, found poem based upon Interview 3, November 13, 2015)

Unpacking Yolanda's experiences. Throughout the process of developing the EE, all of the participants, as emphasized by Yolanda, juggled multiple academic responsibilities. Yolanda also acknowledged the EE was different than other essays she, and her peers, had experienced due to its length and the expectation that they would bring together an argument mindful of different perspectives. In this moment, Yolanda reiterated the points made by several participants in that while she saw the EE as highly relevant for post-secondary preparation, she experienced a dilemma when developing her topic in that she wondered: Should she work on something that demanded more work or revert to a topic with which she was already familiar? For Yolanda, and for the others who wondered about this, they ultimately chose the topic with which they had less experience. Viewing Yolanda's, and other participants', experiences through a sociocognitive perspective (Gee, 
2001), particularly the concept of Discourses ${ }^{8}$ sheds light onto an understanding of an identity that the participants shared in the study. Engaging in the EE meant adopting a mindset that embraced the intellectual challenge of the EE in the midst of multi-tasking other commitments. Finding time for the EE meant participants had to come to terms with the idea that this essay was far different than anything they had encountered: To be completed, it demanded their attention, their acknowledgment of alternative perspectives, and required them to base their claims on evidence. Because of everything else in which they were engaged, the development of the EE was described by participants as a process of false starts in that it was not something that could be done quickly and it needed them to be persistent if it were to be done well. Yolanda's, and the other participants', willingness to persist with the task may be viewed through simply their desire to complete the IBDP of which the EE was a key component. Complicating this view, however, is the point that all of the participants made about the EE, they were willing to persist not only because they learned about the process of developing an authentic research paper, they also learned about themselves in its creation.

\section{Discussion: Viewing Temporal Indicators as Insights into Adolescent Writers'} Knowledge, Motivation and Perceptions of Authenticity: Pedagogical Lessons

The purpose of this study was to better understand how academically engaged students navigated a challenging writing task over the course of 12 months. As students who had experienced success in schools and who were deeply involved in school life, we were curious about the kinds of strategies they would employ to meet the demands of the EE in relation to how they perceived and invested time. Given the importance of writing and the role CDLTs (Benko, 2012, 2016) can play in student learning, it is paramount to consider what role time investment may play upon what is presently known about adolescent writing and motivation. Much has been written about the instructional practices that have been proven to motivate and support the quality of writing produced by adolescents. Of note is Graham and Perin's (2007) in-depth meta-analysis of those intervention strategies found to positively impact the development of student writing, particularly those tasks and topics that tend to motivate adolescents and their willingness to engage in process writing. For the most part, the research shows a strong relationship between adolescent motivation to write and the following elements: freedom to choose a topic (Newkirk \& Kent, 2007), engagement with online audiences (Agger, 2013; Magnifico, 2010; Scott Curwood et al., 2013), and inclusion of multimodal writing (DeVere Wolsey \& Grisham, 2007; Rowsell \& DeCoste, 2012). With the advent of new literacies and the presence of texts, blogs, wikis, tweets, and instant messages (Dowdall, 2006; Gee, 2004; Sternberg, Kaplan, \& Borck, 2007; Witte, 2007), many have advocated for further inquiry into the conditions supporting the motivations of adolescent writers (Collie, Martin, \& Scott Curwood, 2016; Moje et al., 2008; Troia et al., 2012). For example, Agger (2013) argued that in this digital era, youth writing is motivated by the rapid response of others.

Overall, the findings of this study largely affirm what is known about adolescent writers, their habits, dispositions, and motivations. Students do not expect writing to take

\footnotetext{
${ }^{8}$ Gee (2001) suggests Discourses may be understood as comprised of "identity kits... full of specific devices... of which you can enact a specific identity and engage in specific activities associated with that identity" (pp. 719-720).
} 
as long as it does, they have busy lives outside of school, they have limited experience with writing tasks that require research, and they are more willing to invest time in writing when the task is viewed as relevant and there is interest in the topic ${ }^{9}$. Although these ideas are largely known and regarded, as tacit knowledge embedded in the pedagogical repertoires of experienced teachers, there is little consensus regarding the purposes, procedures, and principles of writing tasks that motivationally capture secondary student commitment and interest to engage in writing. One might ask, what can be learned from high achieving adolescents and their writing experiences when they will, in all likelihood, be successful? We suggest that the significance of this study is not necessarily seen through the end products, when participants produced well-crafted writing. Scholars agree that adolescents with strong reading and writing identities tend to succeed (Hall, Johnson, Juzwik, Wortham, \& Mosley, 2009; Guthrie, Wigfield, \& Klauda, 2012; Vetter, 2010). The significance of the study resides in the messiness of events leading up to the completion of the EE, particularly when considering what little is known about what fuels youth stamina in the midst of developing complex writing (Benko, 2016). In light of documented adolescent resistance to writing in school (Agger, 2013; Consalvo \& Maloch, 2015) and the little that is known about adolescent perceptions of writing (Juzwik et al., 2006; Spargur, 2016), let alone writing tasks that intellectually challenge them over time, this is a point of consideration. While this study reaffirms some of what is known about the motivation of adolescent writers in terms of topic interest and perceptions of task authenticity, it also highlights the ways participants temporally distributed (Roca de Larios et al, 2008) their efforts and thinking at different stages of the research writing process.

Viewing participants' writing experiences through temporal constructs (Duncheon \& Tirney, 2013), revealed a critical awareness that developed over time, as participants grew to understand the relationship between their own time investment with the energy, knowledge and skills needed for the development of the EE. Overwhelmingly participants viewed the EE as an authentic task (Behizadeh, 2014a) in that they were able to identify a topic of personal interest, they saw its relevance to their future university studies, and, most importantly, they saw the opportunity to construct new knowledge in ways that were different than prior writing tasks composed for school. The ability to decide if something is authentic, Behizadeh (2014a, 2014b) argued, is a subjective act and is ultimately a decision to be made by learners, and not necessarily teachers' perceptions of a task. Teachers may view a task as authentic, but understanding if learners share this perception is somewhat elusive without insights into their thinking. Considering adolescent descriptions of their writing through a multi-faceted temporal lens, we argue, suggests there is much to be learned from indicators of time as evidence of, substantial or limited, understanding, and motivation, of how to proceed with a task. While educational researchers generally criticize the idea of treating time as a reserve to be tapped for student learning (Compton-Lilly, 2016; Vannest \& Hagan-Burke, 2010), or as a universal concept (Birth, 2004), teachers plan writing to happen in the real-time of schools (VandDerHeide \& Juzwik, 2018). Time in schools tends to be a largely linear, unvarying western construct, with a schedule that does not typically foster conducive writing conditions. Most students cannot write on demand as determined by the blocks of a timetable (Zenkov \& Harmon, 2009). In response, the pedagogy of teachers comes sharply into focus, particularly the

${ }^{9}$ Thank you to the anonymous reviewer who summarized this point.

\begin{tabular}{lll}
\hline Language and Literacy & Volume 21, Issue 1, 2019 & Page 89
\end{tabular}


importance of temporal considerations informing the didactics of writing instruction and its real-time pedagogical actualization. Teachers need to not only plan for variable time allowances at different stages of the writing process, but to also be mindful of the temporal needs of latter stages, once students have completed first drafts. For example, in our study, participants identified how time-intensive some specific writing processes were over others, particularly the stage of argument formulation and review of the literature informing the initial drafts of their EEs. Conversely, participants also described spending less time on revisions of the EE and seemingly had less interest, or awareness, about the importance of recursively polishing their writing as a way to deepen their arguments.

Researchers note that the teaching of writing is not only complex (Applebee \& Langer, 2011; Graham, Early, \& Wilson, 2014), but it is also influenced by contextual supports and constraints (Snow \& Moje, 2010; Stagg Peterson \& McClay, 2014). While a process writing approach (Atwell, 1998; Elbow, 2000; Graves, 1983) explicitly embraces the idea that thoughtful writing happens over time for learners in response to effective teacher pedagogy and feedback, in the backdrop of this complexity, are the less articulated temporal implications of writing. Indeed, cultivating a mindset for writing embraces an understanding that "complete papers are never written, only re-written" (Colyar, 2009, p. 422, author's emphasis). Implied in this statement, but nonetheless important, are the varying temporal implications of different genres and tasks. Not all writing tasks are temporally, or cognitively, equal. Teachers commonly determine the kinds of real-world writing tasks in which secondary youth engage (Muhammad \& Behizadeh, 2015); little is known, however, about how time informs the pedagogical decisions of teachers as they teach writing, and less still about the time perceptions of youth as they engage in writing.

Furthermore, when viewing the research about youth whose motivation to write declines, as they proceed through secondary schooling (Garrett \& Moltzen, 2011; Jeffery \& Wilcox, 2014 Romano, 2007), understanding time as a pedagogical tool becomes an important element. While we note, there are a myriad of factors when understanding learners who experience challenges with literacy (Bauer \& García, 2002; Dawson, 2009; Ganske, Monroe, \& Strickland, 2003; Phegley \& Oxford, 2010, Pitcher, Martinez, Dicembre, Fewster, \& McCormick, 2010), as well as how individuals motivate themselves varies widely (Troia, Shankland, \& Wolbers, 2012), we do argue there is potential in considering the time investment perspectives of adolescents as they write, and to consider its role for those who struggle with writing. Enabling students to have more knowledge of how long writing can take is related to fostering increased metacognition about the writing process (Moje et al., 2008; Snow \& Moje, 2010), an area, we suggest, which holds promise and warrants further inquiry.

\section{Conclusion}

Throughout the study we were frequently reminded that the participants perceived the EE as truly challenging and they struggled in ways that many writers struggle when faced with the development of new arguments, including ourselves. The 10 adolescents involved generously offered windows into their worlds, as they juggled demanding schedules and workloads while completing an original research paper. Knowing how their increased awareness of time played a role in the successful development of the EE, may support the work of those involved in the teaching of writing, and its pedagogy (i.e. teachers, teacher educators), and to consider how the time investment perspectives of 
adolescents reveal indicators of genre knowledge, argument formulation, and motivation into stamina and interest.

\section{References}

Agger, B. (2013). Texting towards utopia: Kids, writing, and resistance. London, UK: Paradigm Publishers.

American Institutes for Research. (2005). Rigor, relevance and results: The quality of teacher assignments and student work in new and conventional high schools. Washington, DC: American Institutes for Research and SRI International.

Retrieved from https://smallhs.sri.com/documents/Rigor_Rpt_10_21_2005.pdf

American Institutes for Research. (2007). Changes in rigor, relevance and student learning in redesigned high schools. Washington, DC: American Institutes for Research and SRI International. Retrieved from https://www.air.org/resource/changes-rigor-relevance-and-student-learningredesigned-high-schools

Applebee, A. N., \& Langer, J. A. (2009). What is happening in the teaching of writing. English Journal, 98(5), 18-28.

Applebee, A. N., \& Langer, J. A. (2011). A snapshot of writing instruction in middle and high schools. English Journal, 100(6), 14-27.

Atwell, N. (1998). In the middle: New understandings about writing, reading, and learning. Portsmouth, NH: Boynton/Cook Publishers.

Aulls, M., \& Shore, B. (2008). Inquiry in education (vol. I): The conceptual foundations for research as a curricular imperative. New York: Erlbaum.

Aulls, M.W. \& Lemay, D. (2013). Exploring the learning benefits and outcomes of the IB extended essay in preparing students for university studies in Canada. Montreal, Quebec, Canada. Department of Educational and Counselling Psychology, McGill University. Retrieved from

https://www.ibo.org/contentassets/d1c0accb5b804676ae9e782b78c8bc1c/mcgillfull reportphase1final.pdf

Aulls, M.W. \& Peláez, S. (2013). Exploring the learning benefits and outcomes of the IB extended essay in preparing students for university studies in Canada: Student perceptions of the impact of the Diploma Programme and the extended essay on the academic demands of first year in university. Montreal, Quebec, Canada.

Department of Educational and Counselling Psychology, McGill University. Retrieved from

https://www.ibo.org/contentassets/d1c0accb5b804676ae9e782b78c8bc1c/mcgillfull reportphase2final.pdf

Bauer, E. B., \& García, G. E. (2002). Lessons from a classroom teacher's use of alternative literacy assessment. Research in the Teaching of English, 36(4), 462494.

Beach, R., Appleman, D., Fecho, B., \& Simon, R. (2016). Teaching literature to adolescents (3rd ed.). New York, NY: Routledge.

Behizadeh, N. (2014a). Adolescent perspectives on authentic writing instruction. Journal of Language \& Literacy Education, 10(1), 27-44. Retrieved from https://files.eric.ed.gov/fulltext/EJ1030675.pdf

Behizadeh, N. (2014b). Xavier's take on authentic writing: Structuring choices for expression and impact. Journal of Adolescent and Adult Literacy, 58(4), 289-298. 
doi:10.1002/jaal.357

Benko, S.L. (2012). Teaching to the task: Preservice teachers' instruction for cognitively demanding writing tasks (Unpublished doctoral dissertation). University of Pittsburgh, Pittsburgh, PA. Retrieved from http://dscholarship.pitt.edu/12309/1/BenkoDissertation-Final060112.pdf

Benko, S. L. (2016). Instruction matters: Secondary English preservice teachers' implementation of cognitively demanding writing tasks. English Education, 48(3), 201-236.

Bonsur Kurki, S.E. (2015). Investigating youth critical literacy engagement. Language and Literacy, 17(3), 13-33.

Bryk A. S., Nagaoka, J. K., and Newmann, F. M. (2000). Chicago classroom demands for authentic intellectual work: Trends from 1997-1999. Chicago: Consortium on Chicago School Research. Retrieved from https://consortium.uchicago.edu/sites/default/files/publications/p0f02.pdf

Butler-Kisber, L. (2002). Artful portrayals in qualitative inquiry: The road to found poetry and beyond. The Alberta Journal of Educational Research, 48(3), 229-239.

Bulter-Kisber, L. \& Stewart, M. (2009). The use of poetic clusters in poetic inquiry. In M. Prendergast, C. Leggo, \& P. Sameshima (Eds.), Poetic inquiry: Vibrant voices in the social sciences (pp. 3-11). Rotterdam: Sense.

Butler-Kisber, L. (2010). Qualitative inquiry: Thematic, narrative and arts-informed perspectives. London, UK: Sage.

Collie, R.J., Martin, A.J., \& Scott Curwood, J. (2016). Multidimensional motivation and engagement for writing: Construct validation with a sample of boys. Educational Psychology, 36(4), 771-791. doi:10.1080/01443410.2015.1093607

Calderón Lòpez, M., \& Thériault, V. (2017). Accessing a 'very, very secret garden': Exploring the literary practices of children and young people using participatory research methods. Language and Literacy, 19(4), 39-54.

Consalvo, A., \& Maloch, B. (2015). Keeping the teacher at arm's length: Student resistance in writing conferences in two high schools. Journal of Classroom Interaction, 50(2), 120-132.

Dawson, C. M. (2009). Beyond checklists and rubrics: Engaging students in authentic conversations about their writing. English Journal, 98(5), 66-71.

DeVere Wolsey, T. \& Grisham, D.L. (2007) Adolescents and the new literacies: Writing engagement. Action in Teacher Education, 29(2), 29-38. doi:10.1080/01626620.2007.10463446

Dowdall, C. (2006). Dissonance between the digitally created worlds of school and home. Literacy, 40(3), 153-163.

Downer, J., Sabol, T. J., \& Hamre, B. (2010). Teacher-child interactions in the classroom: Toward a theory of within- and cross-domain links to children's developmental outcomes. Early Education \& Development, 21, 699-723. doi: $10.1080 / 10409289.2010 .497453$

Duncheon, J.C. \& Tierney, W.G. (2013). Changing conceptions of time: Implications for educational practice. Review of Educational Research, 83(2), 236-272. doi:10.3102/0034654313478492

Fielding, M. \& Bragg, S. (2003). Students as Researchers: Making a Difference. Cambridge: Pearson Publishing. 
Fisher, D. (2009). The use of instructional time in the typical high school classroom. The Educational Forum, 73(2), 168-176. doi:10.1080/00131720902739650

Elbow, P. (2000). Everyone can write: Essays towards a hopeful theory of writing and teaching writing. Oxford, UK: Oxford University Press.

Ganske, K., Monroe, J. K., \& Strickland, D. S. (2003). Questions teachers ask about struggling readers and writers. The Reading Teacher, 57(2), 118-128.

Garrett, L., \& Moltzen, R. (2011). Writing because I want to, not because I have to: Young gifted writers' perspectives on the factors that 'matter' in developing expertise. English Teaching: Practice and Critique, 10(1), 165-180.

Gee, J. (2001). Reading as situated language: A sociocognitive perspective. Journal of Adolescent \& Adult Literacy, 44(8), 714-725. doi:10.1598/JAAL.44.8.3

Gee, J. P. (2004). Game-like situated learning: An example of situated learning and implications for opportunity to learn. Madison: University of Wisconsin.

Gee, J. P. (2007). Social linguistics and literacies: Ideology in discourses (3rd ed.). NewYork, NY: Routledge.

Graham, S., \& Perin, D. (2007). A meta-analysis of writing instruction for adolescent students. Journal of Educational Psychology, 99(3), 445-476.

Graham, S., \& Hebert, M. (2010). Writing to reading: Evidence for how writing can improve reading. Alliance for Excellence in Education. Washington, D.C.

(Commissioned by the Carnegie Corp. of New York). Retrieved from

http://researchbank.acu.edu.au/cgi/viewcontent.cgi?article $=2458 \& a m p=\&$ context=f ea_pub\&amp $=\&$ sei-

redir $=1 \&$ referer $=$ https $\% 253 \mathrm{~A} \% 252 \mathrm{~F} \% 252 \mathrm{Fscholar}$. google.com $\% 252 \mathrm{Fscholar} \% 25$

3Fq\%253DGraham \%25252C\%252520S.\%25252C\%252520\%252526\%252520Heb ert $\% 25252 \mathrm{C} \% 252520 \mathrm{M} . \% 252520 \% 2525282010 \% 252529 . \% 252520 \mathrm{Writing} \% 2525$

20to\%252520reading\%25253A\%252520Evidence\%252520for\%252520how\%2525 20writing\%252520can\%252520improve\%252520reading. \%252520Alliance\%2525 20for $\% 252520$ Excellence $\% 252520 \mathrm{in} \% 252520$ Education. $\% 252520$ Washington $\% 25$ 252C\%252520D.C. $\% 252520 \% 252528$ Commissioned $\% 252520$ by $\% 252520$ the $\% 25$ 2520Carnegie\%252520Corp.\%252520of\%252520New\%252520York\%252529.\#se arch $=\% 22$ Graham $\% 2 \mathrm{C} \% 20 \mathrm{~S} . \% 2 \mathrm{C} \% 20 \% 26 \% 20 \mathrm{Hebert} \% 2 \mathrm{C} \% 20 \mathrm{M} . \% 20 \% 282010$ \%29.\%20Writing\%20reading\%3A\%20Evidence $\% 20$ how $\% 20$ writing $\% 20$ can $\% 20 \mathrm{i}$ mprove\%20reading.\%20Alliance $\% 20$ Excellence $\% 20$ Education. $\% 20$ Washington $\%$ 2C\%20D.C. $\% 20 \% 28$ Commissioned\%20by\%20Carnegie\%20Corp.\%20New\%20Y ork\%29.\%22

Graham, S., Harris, K.R., \& Hebert, M. (2011). Informing writing: The benefits of formative assessment. Alliance for Excellence in Education. Washington, D.C. (Commissioned by the Carnegie Corp. of New York). Retrieved from https://files.eric.ed.gov/fulltext/ED537566.pdf

Graham, S., Early, J., \& Wilcox, K. (2014). Adolescent writing and writing instruction: Introduction to the special issue. Reading and Writing, 27(7), 969-972.

Graves, D. (1983). Writing: Teachers and children at work. Exeter, NH: Heinemann.

Guthrie, J. T., Wigfield, A., \& Klauda, S. L.(2012). Adolescents' engagement in academic literacy. College Park, MD: University of Maryland. Retrieved from http://www.corilearning.com/researchpublications/2012_adolescents_engagement_ebook.pdf 
Hall, L.A., Johnson, S.A., Juzwik, M.M., Worthman, S., \& Mosley, M. (2009). Teacher identity in the context of literacy teaching: Three explorations of classroom positioning and interaction in secondary schools. Teaching and Teacher Education, 26(2), 234-243.

Hamer, D. (2010). The influence of learner factors on the level of achievement in the extended essay (EE) and the theory of knowledge (ToK). Unpublished thesis submitted for the degree of PhD, Melbourne: University of Melbourne. Retrieved from https://minervaaccess.unimelb.edu.au/bitstream/handle/11343/35815/267261_Thesis\%20Hamer.pd $\underline{\text { f? sequence }=1 \& \text { isAllowed }=\mathrm{y}}$

Hillbrecht, M., Zuzanek, J., \& Mannell, R.C. (2008). Time use, time pressure, and gendered behavior in early and late adolescence. Sex Roles, 58, 342-357. doi:10.1007/s11199-007-9347-5

History of the International Baccalaureate. (n.d.). In About the IB [website]. Retrieved from http://www.ibo.org/history/

International Baccalaureate in Nova Scotia. (n.d.). In Nova Scotia Education and Early Childhood Development: International Baccalaureate [website]. Retrieved from http://ib.ednet.ns.ca/in-ns

Inkelas, K, Swan, A, Pretlow, J and Jones, J. 2012. Exploring the benefits of the International Baccalaureate extended essay for university studies at the University of Virginia. Charlottesville, Virginia, USA. Center for Advanced Study of Teaching and Learning in Higher Education, University of Virginia. Retrieved from https://www.ibo.org/globalassets/publications/ibresearch/dp/dpee_uva_summary_2013_05_09.pdf

Rivière, A. (2013). The world studies extended essay: Challenging students on global issues, an interdisciplinary approach. Part 1. The International Schools Journal, $32(2), 16-25$.

Jeffery, J. V., \& Wilcox, K. (2014). "How do it do it if I don't like writing?": Adolescents' stances toward writing across disciplines. Reading and Writing, 27(6), 1095-1117. doi:10.1007/s11145-013-9493-9

Juzwik, M. M., Curcic, S., Wolbers, K., Moxley, K., Dimling, L., \& Shankland, R. (2006). Writing into the 21st century: An overview of research on writing, 1999 to 2004. Written Communication, 23(4), 451-476.

Kalantzis, M., \& Cope, B. (2011). Literacies. New York, NY: Cambridge University Press.

Kane, S. (2011). Literacy \& learning in the content areas (3rd ed.). Scottsdale, AZ: Holcomb Hathaway, Publishers.

Lind, A. (2008). Literacy for all: Making a difference. Paris: UNESCO International Institute for Educational Planning. Retrieved from http://www.unesco.org/new/en/education/themes/education-buildingblocks/literacy/resources/key-publications/

Magnifico, A.M. (2010) Writing for whom? Cognition, motivation, and a writer's audience. Educational Psychologist, 45(3), 167-184. doi:10.1080/00461520.2010.493470 
Matsumura, L. C., Slater, S. C., Garnier, H. E., \& Boston, M. D. (2008). Toward measuring instructional interactions "At-Scale." Educational Assessment, 13(4), 267-300.

Michael, H. \& Mitton-Kükner, J. (2016). Delving into female adolescents leadership experiences in the midst of leading service learning engagements: A qualitative case study. Alberta Journal of Education 62(4), 1-16.

Mitton-Kükner, J. (2015). Problematizing the benefits and challenges of teacher research: Burrowing into female teachers' temporal constraints experienced in the midst of the research process. LEARNing Landscapes, 8(2), 261-283.

Mitton-Kükner, J. (2013). Emerging critical literacy in teachers as novice researchers. Australian Journal of Teacher Education, 38(3), 1-26. Retrieved from http://ro.ecu.edu.au/ajte/vol38/iss3/1

Moje, E., Overby, M., Tysvaer, N., \& Morris, K. (2008). The complex world of adolescent literacy: Myths, motivations, and mysteries. Harvard Educational Review, 78(1), 107-154.

Muhammad, G. E., \& Behizadeh, N. (2015) ."Authentic for whom?: An interview study of desired writing practices for African American adolescent learners, Middle Grades Review, 1(2), 1018. Retrieved from https://scholarworks.uvm.edu/mgreview/vol1/iss2/5

National Commission on Writing for America's Families, Schools, and Colleges. (2003). The neglected " $R$ ": The need for a writing revolution. New York, NY: College Board. Retrieved from https://www.nwp.org/cs/public/download/nwp_file/21478/the-neglected-r-collegeboard-nwp-report.pdf?X-r=pcfile_d

Newmann, F. M., Bryk, A. S., \& Nagaoka, J. (2001). Authentic intellectual work and standardized tests: Conflict or coexistence? Chicago, IL: Consortium on Chicago School Research. Retrieved from https://consortium.uchicago.edu/sites/default/files/publications/p0a02.pdf

Newkirk, T. \& Kent, R. (2007). Teaching the neglected " $r$ ": Rethinking writing instruction in secondary schools. Portsmouth, NH: Heinemann.

Pahl, K., \& Rowsell, J. (2012). Literacy and education: The new literacy studies in the classroom (2nd ed.). London: Sage.

Phegley, M. N., \& Oxford, J. (2010). Cross-level collaboration: Students and teachers learning from each other. English Journal, 99(5), 27-34.

Pitcher, S. M., Martinez, G., Dicembre, E. A., Fewster, D., \& McCormick, M. K. (2010). The literacy needs of adolescents in their own words. Journal of Adolescent \& Adult Literacy, 53(8), 636-645.

Romano, T. (2007). Teaching writing from the inside. In K. Beers, R. Probst, \& L. Rief (Eds.), Adolescent literacy: Turning promise into practice (167-178). Portsmouth, NH: Heinemann.

Roca de Larios, Manchón, R., Murphy, L., \& Marín, J. (2008). The foreign language writer's strategic behavior in the allocaton of time to writing processes. Journal of Second Language Writing, 17, 30-47. doi: 10.1016/j.jslw.2007.08.005

Rowsell, J. \& Decoste, E. (2012). (Re)designing writing in English class: A multimodal approach to teaching writing. Pedagogies: An International Journal, 7(3), 246-260. doi:10.1080/1554480X.2012.685226 
Scott Curwood, J., Magnifico, A.M., \& Lammers, J.C. (2013). Writing in the wild: Writers' motivation in fan-based affinity spaces. Journal of Adolescent \& Adult Literacy, 56(8), 677-685. doi:10.1002/JAAL.192

Shore, B., Birlean, C., Walker, C., Ritchie, K., LaBanca, F. \& Aulls, M. (2009) Inquiry Literacy: A Proposal for a Neologism. LEARNing Landscapes, 3 (1), 139-155.

Snow, C. \& Moje, E. (2010). Why is everyone talking about adolescent literacy?. Kappan, 91(6), 66-69.

Spargur, T. (2016). Struggling adolescent writers describe their experiences (Unpublished doctoral dissertation). Walden University, Minneapolis, MN. Retrieved from https://scholarworks.waldenu.edu/dissertations/2195/

Spear-Swerling, L, \& Zibulsky, J. (2014). Making time for literacy: Teacher knowledge and time allocation in instructional planning. Reading and Writing, 27, 1353-1378. doi:10.1007/s11145-013-9491-y

Stagg Peterson, S. \& McClay, J. (2014). A national study of teaching and assessing writing in Canadian middle grades classrooms. McGill Journal of Education, 49(1), 17-39.

Sternberg, B.J., Kaplan, K.A., \& Borck, J.E. (2007). Enhancing adolescent literacy achievement through integration of technology in the classroom. Reading Research Quarterly, 42(3), 416-420.

Thomson, P., \& Gunter, H. (2006). From 'consulting pupils' to 'pupils as researchers': a situated case narrative. British Educational Research Journal, 32(6), 839-856.

Today in Canada. (n.d). In Nova Scotia Education and Early Childhood Development: International Baccalaureate [website]. Retrieved from http://ib.ednet.ns.ca/history?page=1

Troia, G. A., Shankland, R.K., \& Wolbers, K.A. (2012). Motivation research in writing: Theoretical and empirical considerations. Reading \& Writing Quarterly, 28(1), 528. doi: 10.1080/10573569.2012.632729

United Nations Educational, Scientific and Cultural Organization. (2008). A review of concepts, methodology and current data. Montreal: UNESCO Institute for Statistics. Retrieved from http://unesdoc.unesco.org/images/0016/001628/162808e.pdf

VanDerHeide, J., \& Juzwik, M.M. (2018). Argument as conversation: Students responding writing to significant conversation across time and place. Journal of Adult and Adolescent Literacy, 162(1), 67-77. doi: 10.1002/jaal.754

Villalón, R., Mateos, M., \& Cuevas, I. (2015). High school boys' and girls' writing conceptions and writing self-efficacy beliefs: what is their role in writing performance?. Educational Psychology, 35(6), 653-674. doi:10.1080/01443410.2013.836157

Witte, S. (2007). "That's online writing, not boring school writing": Writing with blogs and the talkback project. Journal of Adult and Adolescent Literacy, 51(2), 92-96.

Vetter, A. (2010). Positioning students as readers and writers through talk in a high school English classroom. English Education, 43, 33-64.

Wray, D. 2013. Student perceptions of the value of the International Baccalaureate extended essay in preparing for university studies. Final Report. Coventry, UK. University of Warwick. Retrieved from 
https://www.ibo.org/contentassets/d1c0accb5b804676ae9e782b78c8bc1c/theibexte ndedessayproject_finalreport_wray.pdf

Zenkov, K, \& Harmon, J. (2009). Picturing a writing process: Photovoice and teaching writing to urban youth. Journal of Adolescent and Adult Literacy, 52(7), 575-584. doi:10.1598/JAAL.52.7.3

\section{Author Biography}

Jennifer Mitton-Kükner is an Associate Professor of Assessment, Secondary Literacy, and Qualitative Research Methods in the Faculty of Education at St. Francis Xavier University in Nova Scotia. Her research interests include adolescent writing and writing instruction, multiliteracies in the content areas, teachers as researchers, and pre-service teachers and the LGBTQ community in schools.

Heather Michael is a Doctoral student in the Department of Curriculum and Teaching at Teachers College, Columbia University, and a graduate from the Masters in Education program at St. Francis Xavier University in Nova Scotia. Her research interests include adolescent identities, sociocultural literacies, and student experiences in the International Baccalaureate Program. 